9. Семиченко В. А. Моделювання структури педагогічної діяльності / В. А. Семиченко. - Ялта: НМЦ «Надія», 2000. - 76 с. 10. Скаткин М. Н. Межпредметные связи, их роль и место в процессе обучения / М.Н. Скаткин, Г. И. Батурина // Межпредметные связи в процессе преподавания основ наук в средней школе: тезисы Всесоюзной конференции (Москва, 10-12 окт. 1973 г.). Ч.1. - М., 1973. - С. 18-24. 11. Сластенин В. А. Общая педагогика: [учеб. пособ. для студ. высш. учеб. завед.] / В. А. Сластенин, И. Ф. Исаев, Е. Н. Шиянов. - М. : ГИЦ ВЛАДОС, 2002. - 475 с. 12. Талызина Н. Ф. Управление процессом усвоения знаний: психологические основы / Н. Ф. Талызина. - М. : Изд-во МГУ, 1984. 344 с. 13. Уемов А. И. Системный подход и общая теория систем / А. И. Уемов. М. : Мысль, 1978. - 272 с.

УДК 37.017 .4

Дар'я Фурт

\title{
ФЕНОМЕН ПОЛІКУЛЬТУРАЛІЗМУ В ПЕДАГОГІЧНОМУ ДИСКУРСІ
}

Фурт Д. В. Феномен полікультуралізму в педагогічному дискурсі.

У статті з'ясовано сутнісні характеристики феномену полікультури як одного зі складників сучасних підходів до навчання 3 позицій осягнення не лише власних національних культурних надбань та знань, а й долучення до знаннєвих цінностей інших країн та народів; здійснено аналіз таких суміжних понять, як «полікультура», «мультикультура», «інтеркультура», «крос-культура».

Ключові слова: культура, полікультура, полікультуралізм, мультикультура, крос-культура, інтеркультура, міжкультурна взаємодія.

Фурт Д. В. Феномен поликультурализма в педагогическом дискурсе.

В статье выявлены особенности феномена поликультуры как одной из составляющих в современных подходах к обучению с позиций постижения не только собственного национального культурного достояния и знаний, но и приобщения к знаниевым ценностям других стран и народов; совершен анализ таких смежных понятий, как «мультикультура», «интеркультура», «кросс-культура».

Ключевые слова: культура, поликультура, поликультурализм, мультикультура, кросс-культура, интеркультура, межкультурное взаимодействие.

Furt D. V. The phenomena of policalture in pedagogical discourse.

In the article essence features are represented to the phenomenon of policulture as one of component modern approaches to teaching from positions of understanding of not only own national cultural properties and knowledge, but also commission to the knowledge values of other countries and nation. The analysis of such contiguous as «moulticulture», «interculture», «crossculture» are represented.

Key words: culture, policulture, moulticulture, crossculture, interculture, culture cooperation.

Концепція полікультурності - важливий складник сучасної загальної освіти, що сприяє засвоєнню учнями знань про інші культури, з'ясуванню загального i особливого (унікального) в традиціях, способі життя, культурних цінностях народів, вихованню в молоді поваги до іншокультурних життєвих і світоглядних цінностей. 
Проблемі виховання та освіти на засадах полікультурності присвячена низка наукових праць (Л. Волик, З. Малькова, О. Столяренко, О. Сухомлинська, О. Джуринський, Л. Голік, О. Гукаленко, В. Болгаріна, Г. Даутова, М. Красовицький, І. Тараненко та інші).

Сучасна вітчизняна освітня система повинна розвиватися на основі діалогу культур (Н. Паперна), розширювати в дітей уявлення про інші народи, формувати толерантність і готовність до продуктивної міжнаціональної і міжкультурної взаємодії (Б. Баркін, А. Гостев, І. Зимня, О. Родіонова та інші).

Метою статmі є вивчення феномену полікультуралізму як компонента та напряму теорії навчання, що тісно пов'язаний 3 поняттями «мультикультура», «інтеркультура», «крос-культура» та зумовлений міжкультурною взаємодією й інтеграцією індивідів у процес взаємодії і взаєморозвитку культур.

Як відзначає М. Симоненко, прийняття концепції полікультурності в теорії навчання як провідної парадигми виховання i навчання має значну цінність. Концепція полікультурної освіти - це не черговий предмет у змісті освіти, не додатковий урок або свято. Усвідомлена необхідність виховання в дітей поваги до культурних відмінностей вимагає від суспільства і держави спеціальних зусиль для проникнення такої педагогіки в життя кожної групи дитячого садка, кожного класу школи, кожної сім’ї [6].

На думку Н. Ничкало, полікультурна освіта покликана розв’язувати двоєдине завдання: освоєння молодим поколінням своєї національної культури і виховання пошани до цінностей інших культур. Продуктивна взаємодія культур у полікультурному суспільстві, яка $є$ і в Україні, - необхідна умова існування i подальшого розвитку [5].

Метою полікультурного навчання, з позиції М. Симоненко, є:

- формування усвідомлених позитивних ціннісних орієнтацій особистості учня стосовно власної культури, полікультурної за своєю природою;

- виховання поваги до історії і культури іншого народу;

- створення полікультурного середовища як основи для взаємодії особистості з елементами інших культур;

- формування здатності учня до особистісного культурного самовизначення;

- формування людини, здатної до активної й ефективної життєдіяльності в багатонаціональному i полікультурному середовищі, яка володіє розвиненим розумінням і відчуттям поваги інших культур, умінням жити в мирі і злагоді 3 людьми різних національностей, рас, переконань і вірувань [6].

Щодо завдань полікультурного навчання, то науковець виокремлює формування у школярів уявлень про культуру і культурне різноманіття; залучення учнів до культурних цінностей народів, що проживають в іншомовних країнах; формування позитивних ціннісних орієнтацій особистості учня щодо своєї та іншої культур; виховання толерантного ставлення учнів до культурних відмінностей, подолання негативних етносоціальних стереотипів; розвиток умінь і навичок продуктивної взаємодії з носіями різних культур; формування у школярів культури міжнаціонального спілкування [6].

Отже, створення полікультурного освітнього середовища дозволить сформувати у молодого покоління готовність і уміння жити у багатонаціональному середовищі, сприятиме формуванню патріота і громадянина не тільки своєї країни, але і світової спільноти. 
3 погляду М. Баяновської та П. Тірали, концепт мультикультурності передбачає залучення відповідних елементів не лише у процес навчання, а й у виховання особистості [1]. А. Панченков підкреслює, що мультикультурне виховання $є$ явищем історично зумовленим, що враховує етнічні особливості та культурні традиції того чи іншого народу [4].

Отже, під мультикультурним вихованням ми розуміємо розвиток у людини здатності шанобливо сприймати етнічну різноманітність і культурну самобутність різних людських груп.

Ф. Фукуяма у своїх працях підкреслює, що мультикультуралізм більш широко розуміють не лише як терпимість та прийняття культурного різноманіття, але і як вимогу законодавчого визнання прав расових, релігійних і культурних груп [8].

Про мультикультуру доцільного говорити не лише в педагогічному, а й у громадянському сенсі, коли мова йде про збереження власної культурної ідентичності попри перебування в оточенні іншої культури (яскравим прикладом $є$ мігранти, які зберігають власну культурну ідентичність незалежно від країни, де перебувають). Отже, мультикультуралізм позначає можливість співіснування різних культур на певній території.

Суміжним із полікультурою, на думку Н. Ничкало, є поняття «інтеркультура», яке також має специфічні риси. Етимологія слова «інтеркультура» пов’язана 3 префіксом «інтер», що буквально означає «між». Тобто інтеркультура як поняття позначає феномен міжкультурної взаємодії. Відповідно, інтеркультурна та міжкультурна взаємодії - тотожні поняття.

Зокрема, інтеркультурна компетентність особистості суб'єкта учіння - це здатність і готовність до діалогу культур на основі комплексу засвоєних лінгвістичних знань, умінь, навичок, знанні сучасної соціокультурної системи країни мови, що вивчається, умінні проводити порівняльний аналіз рідної культури і тієї культури, що вивчається.

У доповіді «Ключові компетентності для Європи» (1996) за програмою Ради Європи обгрунтовано п'ять ключових компетентностей в освіті, однією 3 яких є компетентність, пов'язана 3 життям у багатокультурному суспільстві: «Для того щоб контролювати вияв расизму та ксенофобії, для створення клімату толерантності освіта повинна сприяти формуванню в молодих людей міжкультурних компетенцій, таких, як прийняття відмінностей, повага до інших та здатність існувати поряд із людьми інших культур, мов, релігій» [7].

Як зазначає I. Плужник, міжкультурна комунікативна компетентність - це функціональні вміння розуміти погляди та думки представників інших культур, коректувати власну поведінку, долати конфлікти у процесі комунікації, визнавати право на існування різних цінностей, норм поведінки тощо [5, с. 3].

Отже, основою розвитку міжкультурної компетентності особистості $\epsilon$ формування її інтеркультурної компетентності.

Формування інтеркультурної особистості передбачає введення особистості спочатку в рідну для неї культуру, а потім і в інші культури. Отже, одним із пріоритетних завдань освіти, починаючи вже 3 дошкільного іiі етапу, є формування інтеркультурної компетентності як основи навчання та виховання на засадах полікультурності.

Інтеркультурна компетентність (у iii взаємозв’язку 3 міжкультурною компетентністю) - це складне інтеграційне утворення, що має широкий діапазон компонентів, які $\epsilon$ сукупністю систематичних знань про рідну культуру (етнокультуру), про інші народи і їх культури, умінь і навичок їх практичного 
застосування; розуміння їх своєрідності й цінності, особистісних якостей (ціннісне ставлення до етнокультури, емпатія, толерантність тощо), що сприяють успішній їх адаптації в поліетнічному середовищі.

Методологічну основу інтеркультурної освіти може скласти інтеркультурна комунікація, що грунтується на системному підході до вивчення зарубіжної культури і суспільства, на методі порівняння культурних і соціальних явищ [6]. Поняття інтеркультурної компетентності багатоаспектне і має певні складники лінгвістичну, соціолінгвістичну, соціокультурну, тематичну i навчальну компетенції. Інтеркультурна компетентність визначається також як знання життєвих звичок, вдач, звичаїв, настанов певного соціуму, що формують індивідуальні і групові настанови; індивідуальних мотивацій, форм поведінки, невербальних компонентів (жести, міміка), національно-культурних традицій, системи цінностей.

Розвиток полікультурної спрямованості навчання передбачає формування комунікативної компетентності. В умовах інтеркультури педагогічним завданням $€$ залучення школярів як до національної культури, так і культури інших народів, виховання поваги до самобутності інших народів, розуміння й усвідомлення учнями національно-культурних відмінностей між народами та етносами. Тут постає актуальним шлях пізнання культури народу в діалозі культур. Успішність саморозвитку і комунікації, ефективність соціалізації особистості, передпрофільна підготовка і профільне навчання - ці напрями стають пріоритетними в сучасному навчанні в загальноосвітній школі.

Поняття «крос-культура», будучи суміжним із терміном «полікультура», також має певні відмінності. По-перше, «полікультура» означає сукупність культур, а «крос-культура» позначає радше міжкультурну площину («крос» дослівно означає «через», тобто крос-культура - це деяка магістраль культури, що проходить через усі інші, представлені в сукупності). По-друге, поняття «крос-культура» частіше застосовується як професійно зумовлена і професійно важлива риса особистості фахівця. Із цієї позиції володіння крос-культурною грамотністю і крос-культурною компетентністю дозволяє забезпечити продуктивну міжнаціональну взаємодію. Крос-культурна компетентність, яка $є$ структурним компонентом професійної свідомості, допомагає не лише адекватно діяти в крос-культурному середовищі, але й бути готовим до змін у ньому, бути готовим до самостійної перебудови власної професійної діяльності, якщо того потребуватимуть змінні умови.

Як відзначає А. Науменко, показниками крос-культурної компетентності як інтеграційного явища $\epsilon$ : продуктивні способи реагування в ситуаціях кроскультурної взаємодії, крос-культурна грамотність, етнічна толерантність. Знання, розрізнення і використання продуктивних способів суб'єкт-суб'єктної взаємодії у професійній діяльності сприятиме розвитку міжособових відносин у кроскультурних ситуаціях взаємодії [3].

У статті «Крос-культурний підхід у викладанні іноземної мови студентамфілологам» 3. Бакум та О. Пальчикова зазначають, що важливими завданнями для реалізації крос-культурного підходу в освіті вважаються:

- ознайомлення 3 культурними елементами носіїв мови (свята, традиції, звичаї, обряди);

- ознайомлення 3 національним надбанням (розвиток науки, мистецтва, релігії, історії); 
- ознайомлення із засобами соціокультурної комунікації (правила і норми письма, передача й обмін інформацією за допомогою вербального і невербального спілкування) [2, с. 3-7].

Автори визначають такі головні вимоги до студентів-філологів:

- толерантне ставлення до носіїв іноземної мови;

- терпиме ставлення до культурних особливостей (побут, професійна й особистісна поведінка);

- ідеологічний нейтралітет;

- готовність до сприйняття нової інформації.

Такі вимоги гуманістично спрямовані і сприяють соціалізації особистості в багатомовному світі, що $\epsilon$ передумовою ефективного співробітництва в культурному просторі [2, с. 3-7].

Розглядаючи феномен полікультуралізму в контексті вивчення іноземних мов, слід зупинитися на понятті полікультурної мовної особистості - це особистість, у якої сформовані такі нові компетентності: поліконцептуальна, що дозволяє орієнтуватися в концептосферах різних лінгвокультур; полілінгвістична, що забезпечує можливість використовувати рідну мову як мову міжкультурної комунікації.

А. Панченков підкреслює, що відмінна риса сформованої полікультурної мовної особистості полягає в ㄲï готовності до полікультурного функціонування на всіх рівнях міжкультурної комунікації: загальносвітовому (глобальному), міжетнічному (міжнаціональному), міжособовому [4].

На основі цього можна констатувати, що поліконцептуальна компетентність полікультурної мовної особистості полягає у прагненні під час спілкування 3 людьми іншої культури зрозуміти їхню специфічну систему мови і концепти культури, їх систему ціннісно-смислових орієнтирів, інтегрувати новий досвід у власну систему мови і концепти культури, а також проаналізувати систему власної культури через пізнання нової культури. Отже, в основі поліконцептуальної компетентності - ідея «переформулювання» концептів вітчизняної культури в концепти свого лінгвокультурологічного досвіду.

Полілінгвістична компетентність полікультурної мовної особистості полягає в оволодінні дискурсом як інтегральним процесом, у здатності до мовної рефлексії і критичного мислення в межах різних лінгвокультур.

Отже, основними принципами діяльності вчителя щодо реалізації полікультурної спрямованості мовної підготовки школярів є такі:

- побудова навчального процесу на основі діалогу та взаємодії культур;

- контрастивний принцип оволодіння змістом полікультурної освіти;

- пояснення учням специфічних для іншомовних країн процесів між- i внутрішньоетнічної інтеграції, етнокультурних особливостей кожного народу й етнічної групи;

- виховання поваги i формування інтересу до національних цінностей i особливостей народів іншомовних країн, їхньої мови, способу життя, традицій, віри, національної культури;

- принцип творчої доцільності споживання, збереження і створення нових культурних цінностей.

У результаті вивчення феномену полікультури приходимо до розуміння того, що утвердження нових цінностей суспільства визначається стрімким спрямованим вектором освітніх систем до полікультурної, поліетнічної, полілінгвістичної 
Європи, створення єдиного європейського освітнього простору на теренах світової культури. Виходячи 3 цих принципів, навчання іноземних мов $\epsilon$ необхідним складником навчального процесу вищих навчальних закладів у європейських країнах.

У контексті теми дослідження Н. Ничкало також відзначає, що мова і культура взаємопов'язані, саме тому проблема мовної освіти багатонаціональних держав $є$ провідником у вивченні іншомовних культур різних етнічних угрупувань. У теорії полікультурної освіти є поняття міжкультурного спілкування, із якого виходить, що знання іншомовної культури допомагає в багатьох аспектах зрозуміти свою власну культурну приналежність [5, с. 273].

Отже, актуальність полікультурного підходу до навчання $є$ вагомою, особливо в сучасну епоху стрімкої глобалізації і постійних динамічних змін у різноманітних сферах людської життєдіяльності, зокрема в політичній, економічній, суспільній та освітній. Національні пріоритети в навчанні у поєднанні 3 принципами полікультурної освіти постають на меті формування освітніх стратегій будь-якої країни. Тому значущість полікультурної освіти в навчанні потрібно враховувати в ycix iii аспектах, зокрема й у педагогічному.

Дослідження феномену полікультуралізму в навчанні $\epsilon$ перспективним напрямком, оскільки світова глобалізація спрямовує навчання та розвиток сучасної молоді в нове русло, що в майбутньому допоможе сформувати свідомість людини нового часу, яка здатна мислити i діяти глобально відповідно до вимог поліетнічного середовища, відкрита до взаєморозуміння і взаємодії з носіями різних мов і культур заради миру і злагоди в суспільстві.

\section{Література}

1. Баяновська М. Р. Полікультурне виховання як складник загальнонаціональної системи виховання / М. Р. Баяновська, П. М. Тірала // Відродження. - 1998. - № 3. - С. 30-32. 2. Крос-культурний підхід у викладанні іноземної мови студентам-філологам / 3. Бакум, О. Пальчикова // Теоретична i дидактична філологія : зб. наук. праць. - Вип. 13. - Переяслав-Хмельницький : ФОП Лукашевич, 2012. - С. 3-7. 3. Науменко А. В. Формирование кросскультурной компетентности как структурного компонента профессионального сознания педагога дошкольного образовательного учреждения / А. В. Науменко. Мурманск : МГГУ, 2011. - 111 с. 4. Панченков А. О. Полікультурне виховання в школі / А. О. Панченков // Відкритий урок. - 2001. - № 9-10. - С. 14-18. 5. Професійна освіта в зарубіжних країнах: порівняльний аналіз / за ред. Н. Г. Ничкало, В. О. Кудіна. - Черкаси : Вибір, 2000. - 366 с. 6. Симоненко М. В. Актуальність полікультурної освіти в сучасному суспільстві [Електронний ресурс] / М. В. Симоненко. - Режим доступу: http://www.sworld.com.ua/index.php/ru/pedagogypsychology-and-sociology/theory-and-methods-of-studying-education-and-training/3238smonenko-mb 7. Совет Европы: Симпозиум по теме «Ключевые компетенции для Европы»: Док. DECS / SC / Sec (96)43. - Берн, 1996. 8. Фукуяма Ф. Идентичность и миграция [Електронний ресурс]/ Ф. Фукуяма. - Режим доступу : http://neurope.eu/content/index.php?p=1290. 